\title{
Adoption of Health and Sanitation Technologies among Rural Women: A Psychological Aspects Analysis
}

\author{
Vandana Verma ${ }^{1}$, Ella Rani $^{1}$ and Sarita Verma ${ }^{2}$ \\ ${ }^{1}$ Department of EECM, I.C. College of H.Sc, CCSHAU, Hisar, Haryana, India \\ ${ }^{2}$ Department of Foods and Nutrition, I.C. College of Home Science, CCSHAU, Hisar, India \\ *Corresponding author
}

\section{Keywords \\ Science and technology, \\ Change proneness, Risk \\ orientation, Scientific temper}

\section{Article Info}

Accepted:

07 April 2018

Available Online:

10 May 2018

\section{A B S T R A C T}

Science and technology have had unprecedented impact on economic growth and social development. Knowledge has become a source of economic light and power. This has led to increased restrictions on sharing of knowledge, to new norms of intellectual property rights, and to global trade and technology control regimes. Scientific and Technological developments today also have deep ethical, legal and social implications. The study was conducted in Haryana State. Four districts, two each form eastern and western agro climatic zones were selected randomly. Eight villages from these districts were selected randomly to draw a representative sample of 250 rural women as respondents of the study. Landholding had an association with scientific temper. Type of health care service used during illness is influenced by size of land holding. Probably the income is largely dependent on land holding. With increase in land holding size majority of respondents use city hospital facility. Adoption does depict an increasing positive land with increase in land holding respectively. Size of land holding determines standard of living in rural areas and drainage for water disposal. With increase in land holding size pucca drainage system was adopted by most of the families. Soakage pit technology, a recommended technology found in small per cent of rural families from medium and large land holding. The respondents with semi-medium, medium and large landholdings had medium level of scientific temper whereas the respondents under marginal and landless category had low level of scientific temper i.e. low level of knowledge and understanding regarding science. With increase in land holding size adoption of sanitary napkin by rural women increases.

\section{Introduction}

Science and technology have been an integral part of Indian civilization and culture over the past several millennia. Few are aware that India was the fountain head of important foundational scientific developments are approaches. These cover many great scientific discoveries and technological achievements. A great deal of this traveled outwards from
India. Equally, India also assimilated scientific ideas and techniques from elsewhere, with open-mindedness and a rational attitude characteristic of a scientific ethos. India's traditions have been founded on the principles of universal harmony, respect for all creations and an integrated holistic approach. Since independence, India has been committed to the task of promoting the spread of science and technology to the masses. The key role of 
technology as an important element of national development is also well recognized. These policies have emphasized self reliance, as also sustainable and equitable development. They embody a vision and strategy that are applicable today and would continue to inspire us in our endeavours. Science and Technology achievements include very significant increase in food production, eradication or control of several diseases, increased life expectancy of our citizens and improved quality of life for the people. While, these developments have been highly satisfying, one is also aware of the dramatic changes that have taken place and continue to do so, in the practice of science, in technology developments and their relationship with impact on society. Science and technology in its wide meaning denotes the scientific know-how and the practical art. In fact, science is systematic study and technology is body of knowledge, skill and procedures of making the use of scientific principles for well being of society. The word technology is used loosely to comprise the applications of scientific discovery and the material products which from the central aspects of man. In short technology includes the objects of material cult live. Technologies are bodies of skills, knowledge and procedures for making, using and doing useful things.

Science and technology have had unprecedented impact on economic growth and social development. Knowledge has become a source of economic light and power. This has led to increased restrictions on sharing of knowledge, to new norms of intellectual property rights, and to global trade and technology control regimes. Scientific and Technological developments today also have deep ethical, legal and social implications. In the light of above mentioned facts it has become imperative to conduct an empirical study to find out the psychological aspects and of science and technology for the upliftment of rural women. Hence, the present study with following specific objectives has been under taken.

To find adoption of health and sanitation technologies by rural women.

To assess the psychological aspects in adoption of health and sanitation technologies among rural women.

\section{Materials and Methods}

The study was conducted in Haryana State because of familiarity of researcher with rural scenario conditions, environment and dialect. Four districts, two each form eastern and western agro climatic zones were selected randomly. Accordingly, Yamunanagar, Kurukshetra from eastern zone and Hisar and Fatehabad from western zone were the selected districts. From Hisar district, block I, from Yamunanagar, bilaspur block, from Kukukshetra, block I, and from Fathebad block I was selected randomly. From Yamunagar Distrct Sasoli and Kansapur, from Kurukshetra district Jyotisar and Joganakhera, from Hisar district Salemgarh and Jakhodkhera and from Fatehabad, Matana and Bigharh villages were selected randomly. A total of 250 respondents were selected by drawing pps sampling on basis of land holding from eight selected villages. From Kanaspur, Joganakhera, Salemgarh, Jakhodkhera, Matana and Bigharh thirty respondents were taken from each village. While thirty five respondents were taken from Sasoli and Jyotisar as they were bigger villages. These, 250 respondents were from different land holding categories.

\section{Variables and their measurement}

\section{Adoption}

For the purpose of the present study adoption refers to be the continued use of modern 
household technologies by the rural women. To ascertain the adoption level, the rural women were asked about the actual use of each technology included under different subheads.

A technological grid with different parameters of time of adoption, Use, Key decision-maker, Source of information, Purchase, Relative cost and Purpose of adoption, feasibility was also framed. Adoption of modern household technologies was assessed through semistructured interview schedule and responses of rural women were obtained in Yes/No category. The obtained score were divided in three categories i.e. low adoption, medium adoption and high adoption.

\section{Psychological aspects}

Psychology of individual has a great role in adoption of a technology.

For the present study three psychological aspects viz., scientific temper, change proneness and risk orientation were taken for adoption of health and sanitation technologies.

Scientific temper is defined as a persons' understanding and knowledge regarding science.

There is need to know, how much science does the rural women understand? What are the sources through which they get this information and what is their attitude towards science? In this study, Likert (1932) technique of summated rating was used.

\section{Change proneness}

Change Proneness refers to the substitution of something new for another of something new for another for growth of the society for better living. This was measured by modified selfrating scale of Moulik (1965).

\section{Risk orientation}

It refers to respondent's risk taking capacity and courage to face various types of problems encountered. This was measured by using risk preference scale developed by Supe (1969). The scale consisted of five statements. The responses were obtained under five point rating scale as strongly agree, agree, neutral, disagree and strongly disagree with scores of $5,4,3,2$ and 1 respectively.

\section{Results and Discussion}

Adoption of health and sanitation technologies in rural homes according to land holding

Health and sanitation technologies have a important influence on the health of family members. Adoption of these technologies according to land holdings is depicted in Table 1.

\section{During illness}

Table 1 depicts information on the issue of, when members of household get sick, where, do they generally go for treatment as presented shows that from marginal land holding households 51.85 per cent of rural women normally resort to taking home treatment, 44.40 per cent got to PHC and 14.81 per cent go to city hospital.

From small land holding households 55.17 per cent of women go to PHC, 31.03 per cent got to city hospitals, 31.03 per cent take home treatment. However, semi-medium land holding households 38.88 per cent of rural women go to city hospital, 33.33 per cent go to $\mathrm{PHC}$ and 29.16 per cent take home treatment. In the medium land holding category, during illness 56.36 per cent of rural women go to city hospital, 43.63 per cent to PHC and 7.27 per cent takes home treatment. 
From large land holding category 85.00 per cent go to city hospital and 47.50 per cent go to PHC.

Hence, it can be concluded that the type of health care service used during illness is influenced by size of land holding. Probably the income is largely dependent on land holding. With increase in land holding size majority of respondents use city hospital facility. Hospitals are the most popular source of health care in large land holding households while majority of the respondents form marginal households either take home treatment or go to PHC and those from small, semi-medium and medium go to city hospital followed by PHC. Thus, the type of health services used was being influenced by land holding size. Those who can offer to pay for medical facilities use private hospitals in city to a larger extent.

\section{Immunization}

Immunization is the health care practice which is adopted for children and pregnant. Details on adoption on basis of land holding as presented in Table 1 show that. From marginal land holding household 79.61 per cent of children and 68.51 per cent of pregnant women use this practice. However, from small land holding households 82.75 per cent of rural women got immunized during pregnancy while percentage of children immunized were 86.20 per cent. From semi-medium land holding households 93.05 per cent of rural women got immunization during pregnancy, while 91.66 per cent of children got immunized from this category of land holding. In the category of medium land holding category 92.72 per cent of rural women got immunization during pregnancy and children 96.36 per cent. From large land holding households 92.50 per cent of rural women got immunization during pregnancy, while children got immunization were ninety five per cent. The overall adoption was 86.40 and 90.00 per cent respectively. This reason for a high adoption in all categories may be due to regular campaigns of immunization and free medicines availability. Adoption does depict an increasing positive land with increase in land holding respectively.

\section{Modern methods of family planning}

An important indication of the quality of life is to estimate the extent of adoption of modern family planning methods. Form data in table it is evident that among marginal land holding household 57.40 per cent of rural women use pills while 42.60 per cent of rural women had adopted female sterilization method. Form small land holding households the methods used were pills $(62.06 \%)$, female sterilization $(31.03 \%)$ and IUD (6.91\%).

However in semi-medium land holding households rural women use method of pills (75.00\%), female sterilization (13.88\%) and IUD (11.12\%). From medium land holding households the method used by rural women were pills $(74.55 \%)$, female sterilization $(10.90 \%)$ and IUD (14.55\%). It can be clearly seen that among large land holding households the method used were polls $(77.50 \%)$, female sterilization (7.50\%) and IUD (15.00\%). The overall adoption for pill, female sterilization and IUD was 76 per cent, 20.40 and 9.60 per cent, respectively.

Hence, it can be concluded that pills were the popular family planning method among rural women.

\section{Sanitary napkin}

The overall adoption rate for this technology was 27.60 per cent with large variation between land holding categories. Rural women belonging to marginal land holding household had very low adoption of sanitary 
napkin $(5.55 \%)$. However with increase in land holding size adoption of this also increases marginally i.e. from small land holding household adoption of sanitary napkin was 20.68 per cent while twenty five per cent of rural women from semi-medium land holding adopted sanitary napkin, while adoption of this was 34.54 per cent in medium land holding household families and the percentage of rural women who adopted sanitary napkin from large land holding was 57.50 per cent.

Hence, it can be concluded that with increase in land holding size adoption of sanitary napkin by rural women increases.

\section{Garbage disposal}

Garbage disposal in a home depicts its standard of living and affects health status of family members. Table 1 depicts that among marginal land holding household majority of rural women $(85.19 \%)$ dispose garbage in heaps, while only 14.81 per cent disposed it in compost pit. Percentages of rural women who dispose their household garbage in garbage heap were 82.76 per cent household, while only 17.24 per cent dispose garbage in compost pit. From semi-medium land holding household 59.72 per cent of rural families dispose garbage in garbage heap, while 40.28 per cent garbage in compost pit. In medium size land holding percentage of rural household families who use method of garbage heap and compost pit were 59.55 per cent and 45.45 per cent, respectively. From large land holding 52.50 per cent and 47.50 per cent of rural families dispose garbage in garbage heap and compost pit respectively. No one had adopted vermi-composting technology. On the whole 65.60 and 34.40 per cent families disposed garbage in garbage heap and compost pit, respectively. It is also noted that with increase landholding respondents used composite pit to a greater extent.

\section{Water disposal}

In rural areas water disposal is a major problem. From Table 1 it is noted that for the group of respondents majority of rural families $(37.60 \%)$ had katcha drainage for water disposal, while 2.40 per cent had soakage pit. On land holding basis, majority marginal land holding had katcha drainage $(50.00 \%)$, while 44.44 per cent had no drains and only 5.56 per cent had pucca drainage. From small land holding households 48.27 per cent had katcha drainage followed by pucca drainage by 27.59 per cent yet at the same time 24.13 per cent had no drainage.

From semi-medium land holding household 38.89 per cent rural families had pucca drainage in their homes followed by 36.11 per cent who had katcha drainage while 25 per cent had no drains. Majority of rural families $(43.64 \%)$ from medium land holding household had pucca drainage, 32.73 per cent had katcha drainage, 20 per cent had no drainage and only 3.63 per cent had adopted soakage pit technology. From large land holding households majority of rural families $(62.50 \%)$ had adopted pucca drainage system followed by katcha drainage $(22.50 \%)$ and soakage pit technology by 10.00 per cent and 5.00 per cent had no drains.

Hence it can be concluded that size of land holding determines standard of living in rural areas and drainage for water disposal. With increase in land holding size pucca drainage system was adopted by most of the families. Soakage pit technology, a recommended technology found in small per cent of rural families from medium and large land holding.

\section{Place of defecation}

Defecation is a national system while privacy and water facility is important at the spot of defecation. 
Table.1 Adoption of health and sanitation technologies among rural women according to land holding

\begin{tabular}{|c|c|c|c|c|c|c|c|c|c|c|c|c|c|}
\hline \multirow{3}{*}{$\begin{array}{l}\text { Sr. } \\
\text { No. }\end{array}$} & \multirow{3}{*}{$\begin{array}{l}\text { Technology } \\
\text { land holding }\end{array}$} & \multicolumn{12}{|c|}{ Percentage adoption of health and sanitation technology } \\
\hline & & \multicolumn{2}{|c|}{ Marginal } & \multicolumn{2}{|c|}{ Small } & \multicolumn{2}{|c|}{ Semi-medium } & \multicolumn{2}{|c|}{ Medium } & \multicolumn{2}{|c|}{ Large } & \multicolumn{2}{|c|}{ Total } \\
\hline & & Freq. & $\%$ & Freq. & $\%$ & Freq. & $\%$ & Freq. & $\%$ & Freq. & $\%$ & Freq. & $\%$ \\
\hline 1. & $\begin{array}{l}\text { During illness } \\
\text { - PHC } \\
\text { - City hospital } \\
\text { - Home treatment }\end{array}$ & $\begin{array}{c}24 \\
8 \\
28\end{array}$ & $\begin{array}{l}44.40 \\
14.81 \\
51.85\end{array}$ & $\begin{array}{c}16 \\
9 \\
9\end{array}$ & $\begin{array}{l}55.17 \\
31.03 \\
31.03\end{array}$ & $\begin{array}{l}24 \\
28 \\
21\end{array}$ & $\begin{array}{l}33.33 \\
33.88 \\
29.16\end{array}$ & $\begin{array}{c}24 \\
31 \\
4\end{array}$ & $\begin{array}{c}43.63 \\
56.36 \\
7.27\end{array}$ & $\begin{array}{c}19 \\
34 \\
0\end{array}$ & $\begin{array}{c}47.50 \\
85.00 \\
0.00\end{array}$ & $\begin{array}{c}107 \\
110 \\
62\end{array}$ & $\begin{array}{l}42.80 \\
44.00 \\
24.80\end{array}$ \\
\hline 2. & $\begin{array}{l}\text { Immunization } \\
\text { - During } \\
\text { pregnancy } \\
\text { - Children }\end{array}$ & $\begin{array}{l}37 \\
43\end{array}$ & $\begin{array}{l}68.51 \\
79.62\end{array}$ & $\begin{array}{l}24 \\
25\end{array}$ & $\begin{array}{l}82.75 \\
86.20\end{array}$ & $\begin{array}{l}67 \\
66\end{array}$ & $\begin{array}{l}93.05 \\
91.66\end{array}$ & $\begin{array}{l}51 \\
53\end{array}$ & $\begin{array}{l}92.72 \\
96.36\end{array}$ & $\begin{array}{l}37 \\
38\end{array}$ & $\begin{array}{l}92.50 \\
95.00\end{array}$ & $\begin{array}{l}216 \\
225\end{array}$ & $\begin{array}{l}86.40 \\
90.00\end{array}$ \\
\hline 3. & $\begin{array}{l}\text { Modern method of } \\
\text { family planning } \\
\text { - Pill } \\
\text { - Female sterli. } \\
\text { - IDU }\end{array}$ & $\begin{array}{c}31 \\
23 \\
0\end{array}$ & $\begin{array}{c}57.40 \\
42.60 \\
0.00\end{array}$ & $\begin{array}{c}18 \\
9 \\
2\end{array}$ & $\begin{array}{c}62.06 \\
31.03 \\
6.91\end{array}$ & $\begin{array}{c}54 \\
10 \\
8\end{array}$ & $\begin{array}{l}75.00 \\
13.88 \\
11.12\end{array}$ & $\begin{array}{c}41 \\
6 \\
8\end{array}$ & $\begin{array}{l}74.55 \\
10.90 \\
14.55\end{array}$ & $\begin{array}{c}31 \\
3 \\
6\end{array}$ & $\begin{array}{c}77.50 \\
7.50 \\
15.00\end{array}$ & $\begin{array}{c}175 \\
51 \\
24\end{array}$ & $\begin{array}{c}70.00 \\
20.40 \\
9.60\end{array}$ \\
\hline 4. & Sanitary Napkin & 3 & 5.55 & 6 & 20.68 & 18 & 25.00 & 19 & 34.54 & 23 & 57.50 & 69 & 27.60 \\
\hline 5 . & $\begin{array}{l}\text { Garbage disposal } \\
\text { - Garbage heap } \\
\text { - Compost pit } \\
\text { - Vermin-compost. }\end{array}$ & $\begin{array}{c}46 \\
8 \\
0\end{array}$ & $\begin{array}{c}85.19 \\
14.81 \\
0.00\end{array}$ & $\begin{array}{c}24 \\
5 \\
0\end{array}$ & $\begin{array}{c}82.76 \\
17.24 \\
0.00\end{array}$ & $\begin{array}{c}43 \\
19 \\
0\end{array}$ & $\begin{array}{c}59.72 \\
40.28 \\
0.00\end{array}$ & $\begin{array}{c}30 \\
25 \\
0\end{array}$ & $\begin{array}{c}54.55 \\
45.45 \\
0.00\end{array}$ & $\begin{array}{c}21 \\
19 \\
0\end{array}$ & $\begin{array}{c}52.50 \\
47.50 \\
0.00\end{array}$ & $\begin{array}{c}164 \\
86 \\
0\end{array}$ & $\begin{array}{c}65.60 \\
34.40 \\
0.00\end{array}$ \\
\hline 6. & $\begin{array}{l}\text { Water disposal } \\
\text { - Katcha drainage } \\
\text { - Pucca drainage } \\
\text { - No drains } \\
\text { - Soakage pit }\end{array}$ & $\begin{array}{c}27 \\
3 \\
24 \\
0\end{array}$ & $\begin{array}{c}50.00 \\
5.56 \\
44.44 \\
0.00\end{array}$ & $\begin{array}{l}14 \\
8 \\
7 \\
0\end{array}$ & $\begin{array}{c}48.27 \\
27.59 \\
24.13 \\
0.00\end{array}$ & $\begin{array}{c}26 \\
28 \\
18 \\
0\end{array}$ & $\begin{array}{c}36.11 \\
38.89 \\
25.00 \\
0.00\end{array}$ & $\begin{array}{c}18 \\
24 \\
11 \\
2\end{array}$ & $\begin{array}{c}32.73 \\
43.64 \\
20.00 \\
3.63\end{array}$ & $\begin{array}{c}9 \\
25 \\
2 \\
4\end{array}$ & $\begin{array}{c}22.50 \\
62.50 \\
5.00 \\
10.00\end{array}$ & $\begin{array}{c}94 \\
88 \\
62 \\
6\end{array}$ & $\begin{array}{c}37.60 \\
35.20 \\
24.80 \\
2.40\end{array}$ \\
\hline $\begin{array}{l}7 . \\
\text { (i) }\end{array}$ & $\begin{array}{l}\text { Toilet Place } \\
\text { - Open defecation } \\
\text { - Pit laterine } \\
\text { - Sanitary laterine }\end{array}$ & $\begin{array}{c}41 \\
2 \\
11\end{array}$ & $\begin{array}{c}75.92 \\
3.70 \\
20.37\end{array}$ & $\begin{array}{c}19 \\
4 \\
6\end{array}$ & $\begin{array}{l}65.52 \\
13.79 \\
20.68\end{array}$ & $\begin{array}{l}11 \\
19 \\
42\end{array}$ & $\begin{array}{l}15.28 \\
26.38 \\
58.33\end{array}$ & $\begin{array}{c}5 \\
12 \\
38\end{array}$ & $\begin{array}{c}9.09 \\
21.80 \\
69.10\end{array}$ & $\begin{array}{c}2 \\
8 \\
30\end{array}$ & $\begin{array}{c}5.00 \\
20.00 \\
75.00\end{array}$ & $\begin{array}{c}78 \\
45 \\
127\end{array}$ & $\begin{array}{l}31.20 \\
18.00 \\
50.80\end{array}$ \\
\hline (ii) & $\begin{array}{l}\text { Water facility in } \\
\text { laterine } \\
\text { - Stored water } \\
\text { - Tap water } \\
\text { - Carry water every } \\
\text { time from outside }\end{array}$ & $\begin{array}{c}1 \\
0 \\
12\end{array}$ & $\begin{array}{c}7.69 \\
0.00 \\
92.31\end{array}$ & $\begin{array}{l}2 \\
3 \\
5\end{array}$ & $\begin{array}{l}20.00 \\
30.00 \\
50.00\end{array}$ & $\begin{array}{c}8 \\
6 \\
47\end{array}$ & $\begin{array}{c}13.11 \\
9.84 \\
77.05\end{array}$ & $\begin{array}{c}7 \\
12 \\
31\end{array}$ & $\begin{array}{l}14.00 \\
24.00 \\
62.00\end{array}$ & $\begin{array}{c}5 \\
26 \\
7\end{array}$ & $\begin{array}{l}13.15 \\
68.42 \\
18.43\end{array}$ & $\begin{array}{c}23 \\
47 \\
102\end{array}$ & $\begin{array}{l}13.37 \\
27.33 \\
59.30\end{array}$ \\
\hline (iii) & $\begin{array}{l}\text { Location of laterine } \\
\text { - Inside the home } \\
\text { - Outside the home } \\
\text { - Away from home }\end{array}$ & $\begin{array}{l}0 \\
9 \\
4\end{array}$ & $\begin{array}{c}0.00 \\
69.23 \\
30.77\end{array}$ & $\begin{array}{l}3 \\
4 \\
3\end{array}$ & $\begin{array}{l}30.00 \\
40.00 \\
30.00\end{array}$ & $\begin{array}{c}7 \\
46 \\
8\end{array}$ & $\begin{array}{l}11.48 \\
75.41 \\
13.11\end{array}$ & $\begin{array}{c}9 \\
41 \\
0\end{array}$ & $\begin{array}{c}18.00 \\
82.00 \\
0.00\end{array}$ & $\begin{array}{c}4 \\
34 \\
0\end{array}$ & $\begin{array}{c}10.52 \\
89.48 \\
0.00\end{array}$ & $\begin{array}{c}23 \\
134 \\
15\end{array}$ & $\begin{array}{c}13.38 \\
77.90 \\
8.72\end{array}$ \\
\hline $\begin{array}{l}8 . \\
\text { (i) }\end{array}$ & $\begin{array}{l}\text { Bathroom place } \\
\text { - Part of room } \\
\text { - Open court yard } \\
\text { (temporary } \\
\text { arrangement) } \\
\text { - Separate bathroom }\end{array}$ & $\begin{array}{l}24 \\
17\end{array}$ & $\begin{array}{l}44.45 \\
31.48 \\
\\
24.07\end{array}$ & $\begin{array}{l}9 \\
4\end{array}$ & $\begin{array}{r}31.03 \\
13.80 \\
\\
55.17\end{array}$ & $\begin{array}{c}14 \\
8\end{array}$ & $\begin{array}{l}19.45 \\
11.11 \\
69.44\end{array}$ & $\begin{array}{c}10 \\
4\end{array}$ & $\begin{array}{c}18.18 \\
7.28 \\
74.54\end{array}$ & $\begin{array}{l}5 \\
0\end{array}$ & $\begin{array}{c}12.50 \\
0.00 \\
87.50\end{array}$ & $\begin{array}{l}62 \\
33\end{array}$ & $\begin{array}{l}24.80 \\
13.20 \\
62.00\end{array}$ \\
\hline (ii) & $\begin{array}{l}\text { Water facility } \\
\text { - } \quad \text { Stored water } \\
\text { - } \quad \text { Tap water } \\
\text { - Carry water every } \\
\text { time from outside }\end{array}$ & $\begin{array}{c}4 \\
0 \\
50\end{array}$ & $\begin{array}{c}7.40 \\
0.00 \\
92.60\end{array}$ & $\begin{array}{c}2 \\
1 \\
26\end{array}$ & $\begin{array}{c}6.90 \\
3.45 \\
89.65\end{array}$ & $\begin{array}{c}7 \\
5 \\
60\end{array}$ & $\begin{array}{c}9.72 \\
6.94 \\
83.34\end{array}$ & $\begin{array}{c}6 \\
10 \\
39\end{array}$ & $\begin{array}{l}10.90 \\
18.18 \\
70.92\end{array}$ & $\begin{array}{c}3 \\
24 \\
13\end{array}$ & $\begin{array}{c}7.50 \\
60.00 \\
32.50\end{array}$ & $\begin{array}{l}22 \\
40 \\
93\end{array}$ & $\begin{array}{l}14.20 \\
25.80 \\
60.00\end{array}$ \\
\hline
\end{tabular}


Table.2 Scientific temper and adoption of health and sanitation technologies

\begin{tabular}{|c|c|c|c|c|c|c|}
\hline \multirow{2}{*}{$\begin{array}{l}\text { Scientific temper } \\
\text { Technologies }\end{array}$} & \multicolumn{2}{|c|}{ Low } & \multicolumn{2}{|c|}{ Medium } & \multicolumn{2}{|c|}{ High } \\
\hline & Freq. & $\%$ & Freq. & $\%$ & Freq. & $\%$ \\
\hline \multicolumn{7}{|c|}{ Health \& Sanitation } \\
\hline Low & 41 & 16.40 & 25 & 10.00 & 0 & 0.00 \\
\hline Medium & 29 & 11.60 & 106 & 42.40 & 6 & 2.40 \\
\hline High & 7 & 2.80 & 13 & 5.20 & 23 & 9.20 \\
\hline $\mathrm{COC}=.54$ & & & & & $\chi^{2} 10$ & \\
\hline
\end{tabular}

Table.3 Risk orientation and change proneness and adoption level

\begin{tabular}{|l|c|c|c|c|c|c|}
\hline \multicolumn{1}{|c|}{ Risk Orientation } & \multicolumn{2}{|c}{ Low } & \multicolumn{2}{c|}{ Medium } & \multicolumn{2}{c|}{ High } \\
\hline & Freq. & \% & Freq. & \% & Freq. & \% \\
\hline Health \& Sanitation & & & & & & \\
\hline Low & 52 & 20.80 & 14 & 5.60 & 0 & 0.00 \\
\hline Medium & 24 & 9.60 & 110 & 4.00 & 7 & 2.80 \\
\hline High & 2 & 0.80 & 13 & 5.20 & 28 & 11.20 \\
\hline COC=.54 & & & & & & $\chi^{\mathbf{2}} \mathbf{1 0 5 . 0 8}$ \\
\hline Change Proneness & & & & & & \\
\hline Health \& Sanitation & & & & & & \\
\hline Low & 41 & 16.40 & 25 & 10.00 & 0 & 0.00 \\
\hline Medium & 22 & 8.80 & 108 & 43.20 & 11 & 4.40 \\
\hline High & 0 & 0.00 & 11 & 4.40 & 32 & 12.80 \\
\hline COC=.60 & & & & & & $\chi^{\mathbf{2}} \mathbf{1 4 4 . 0 3}$ \\
\hline
\end{tabular}

In rural areas open defecation is being replaced by sanitary latrines, either within the household or nearly from table 1 it is seen that from marginal land holding households majority of rural families (75.92\%) followed open defecation system followed by families having sanitary laterine $(20.37 \%)$ while 3.70 per cent of families also had pit laterine. Percentage of households having open defecation from small land holding households was 65.52 per cent followed by 20.68 per cent of rural families having sanitary latrine, while 13.79 per cent had pit latrines. Majority of families (58.33\%) from semi-medium land holding household had sanitary laterine followed by 26.38 per cent of rural families having pit laterine and 15.28 per cent of rural families followed open defecation. From medium land holding households majority of rural home adopted sanitary laterine i.e. 69.10 per cent followed by 21.80 per cent of rural families who had adopted pit laterine in their homes while only 9.09 had followed open defecation system.

Seventy five per cent of rural families had adopted sanitary latrines from large land holding household while twenty per cent had pit latrines in their home. Only five per cent had open defecation system.

On the whole the overall picture that emerges is that with increase in land holding sanitary condition in terms of sanitary latrine also improved.

\section{Location of laterine}

From marginal land holding households the families having laterine facility, 69.23 per cent had this facility outside the home while 30.77 per cent had this away from home. From small land holding household 40.00 per cent of household had laterine outside the 
home while 30.00 per cent had this inside the home and 30.00 per cent had laterine away from home.

Percentage of household having laterine outside the home was 75.41 per cent and 13.11 per cent had this away from home and 11.48 per cent had this inside the home among semi-medium land holding households.

From medium land holding households majority of rural families $(82.00 \%)$ had laterines outside the home while only 18.00 per cent had this inside the home.

Among large land holding households majority of rural families i.e. 89.48 per cent had laterines outside the home and 10.52 per cent households had this inside the home.

\section{Water facility in laterine}

From marginal land holding households majority of families $(92.31 \%)$ had no water facility in laterine and carry water every time from outside while 7.69 per cent had stored water facility in laterine. Among small land holding household majority of families $(50.00 \%)$ had no water facility and carried water every time from outside. Thirty per cent of rural families had tap water facility and twenty per cent had stored water facility in toilet.

From semi-medium land holding household 77.05 had no water facility in laterine and carry water every time from outside followed by 13.11 per cent of rural families who had stored water facility in toilet and only 9.84 per cent who had tap water facility in laterines.

Sixty two per cent of rural families from medium land holding household had no water facility in toilet and carry water every time from outside while twenty four per cent had tap water and only fourteen per cent had stored water facility in toilets. Majority of rural families $(68.42 \%)$ from large land holding households had tap water facility while 18.43 per cent had not water facility and carry water every time from outside. Only 13.15 per cent had stored water facility in toilet.

\section{Place of taking bath}

Among marginal land holding household 75.93 per cent had no separate bathroom. Out of this 44.45 per cent of rural women use part of room for bathing and 31.48 per cent of rural women use open courtyard for bathing by making temporary arrangements while 24.07 per cent had separate bathroom.

From small land holding households majority of rural women i.e. 55.17 per cent had separate bathroom in their homes. Although 44.83 had no bathroom facility in their homes, among this 31.03 per cent use part of room as bathroom while 13.80 per cent use open courtyard by making temporary arrangements as bathroom. Percentage of households having separate bathroom was 69.44 per cent among semi-medium land holding household while 19.45 per cent and 11.11 per cent of rural women were using part of room and open courtyard as bathroom respectively.

Majority of rural women (74.54\%) were having separate bathroom in their homes from medium land holding household, while 18.18 per cent of rural women were using part of room as bathroom.

Only 7.28 per cent of rural women were making temporary arrangements in courtyard for bathing. Among large land holding households majority of rural women i.e. 87.50 per cent had separate bathroom in their homes, while 12.50 per cent of rural women were using part of room as bathroom. 
Scientific temper and adoption of health and sanitation technologies

Respondents with low scientific temper had low adoption (16.4\%), medium adoption $(11.6 \%)$ and high adoption (2.8\%). However, among medium scientific tempered rural women majority of women $(42.4 \%)$ had medium adoption, 10 per cent had low adoption and 5.2 per cent had low adoption regarding health and sanitation technologies. Further, rural women with high scientific temper had high adoption (9.2\%) and 2.4 per cent had medium adoption regarding health and sanitation technologies. Chi-square calculated was 103.95 which show significant association and contingency coefficient was 0.54 showing strong association (Table 2 ).

\section{Risk orientation and adoption of health and sanitation technologies}

Regarding health and sanitation technologies respondents with low risk orientation had low to high adoption i.e. 20.80 per cent, 9.60 per cent and 0.80 per cent respectively. Further, rural women with medium risk orientation had medium adoption (44\%) followed by low adoption (5.6\%) and high adoption (5.2\%). Respondents having high risk orientation had high adoption (11.20\%) and medium adoption $(2.8 \%)$ shows that with changes in risk capacity from low to high, adoption of technology also differs from low to high. Chisquare calculated was 105.08, shows significant association and contingency coefficient was 0.54 showing strong association (Table 3 ).

\section{Change proneness and adoption of health and sanitation technologies}

Regarding health and sanitation technologies among low change proneness category 16.40 per cent had low adoption followed by 8.80 per cent with medium adoption. Among medium change proneness category majority of rural women (43.2\%) had medium adoption followed by 10 per cent of rural women with low adoption and only 4.4 per cent had high adoption. Further, among high change proneness category 12.8 per cent had high adoption, followed by 4.4 per cent of rural women with medium adoption. Chisquare calculated was 144.03, shows significant association and contingency coefficient was 0.60 showing strong association (Table 3). It can be concluded that scientific and Technological developments today also have deep ethical, legal and social implications. Landholding had an association with scientific temper. Type of health care service used during illness is influenced by size of land holding. Probably this is so in income is largely dependent on land holding. With increase in land holding size majority of respondents use city hospital facility. Adoption does depict an increasing positive land with increase in land holding respectively. Size of land holding determines standard of living in rural areas and drainage for water disposal. With increase in land holding size pucca drainage system was adopted by most of the families. Soakage pit technology, a recommended technology found in small per cent of rural families from medium and large land holding. The respondents with semi-medium, medium and large landholdings had medium level of scientific temper whereas the respondents under marginal and landless category had low level of scientific temper i.e. low level of knowledge and understanding regarding science. With increase in land holding size adoption of sanitary napkin by rural women increases.

\section{References}

Karwasra, S. 2001. Introduction of household sanitation technology package among 
slum dwellers, Ph. D. Thesis, Dept. of F.R.M. CCSHAU, Hisar.

Khan, S. 2003. Socio-economic dimensions of science and technology for integrated rural development of Mewat in Haryana. Ph.D. HAU, Hisar.

Mahajan, N. 2007. Measurement of adoption behaviours of mothers and women beneficiaries of ICDS programmes in respect of adoption of nutrition, health and hygiene technology. Indian Journal of Extension Education.

Malhotra, S.P. and Sen, M.L.A. 2006. Socioeconomic characteristics of small, medium and large size of households in a desert heat. Journal of Family Welfare (13) 2.

Panicker, P.V.R.C. 2010. Rural SanitationHow to improve. Swasth Hind 24(2): 36-37.

\section{How to cite this article:}

Vandana Verma and Ella Rani. 2018. Adoption of Health and Sanitation Technologies among Rural Women: A Psychological Aspects Analysis. Int.J.Curr.Microbiol.App.Sci. 7(05): 449458. doi: https://doi.org/10.20546/ijcmas.2018.705.057 